\title{
Factory Draughtsmen in Eighteenth- and Nineteenth-Century France
}

The Forgotten Artists of the Workshop

Le dessinateur de fabrique, dans l'ombre de l'atelier (XVIII'-XIX ${ }^{e}$ siècle)

¿Cómo diseñar la moda? Gestos ordinarios y prácticas cotidianas (siglos XVIII-

XIX)

\section{Audrey Millet}

Translator. Jean-Yves Bart

\section{OpenEdition}

\section{Journals}

Electronic version

URL: http://journals.openedition.org/bssg/106

DOI: $10.4000 /$ bssg. 106

ISSN: 2490-9424

Publisher

Presses universitaires de Vincennes

Electronic reference

Audrey Millet, "Factory Draughtsmen in Eighteenth- and Nineteenth-Century France", Biens

Symboliques / Symbolic Goods [Online], 1 | 2017, Online since 15 October 2017, connection on 04

March 2021. URL: http://journals.openedition.org/bssg/106 ; DOI: https://doi.org/10.4000/bssg.106 

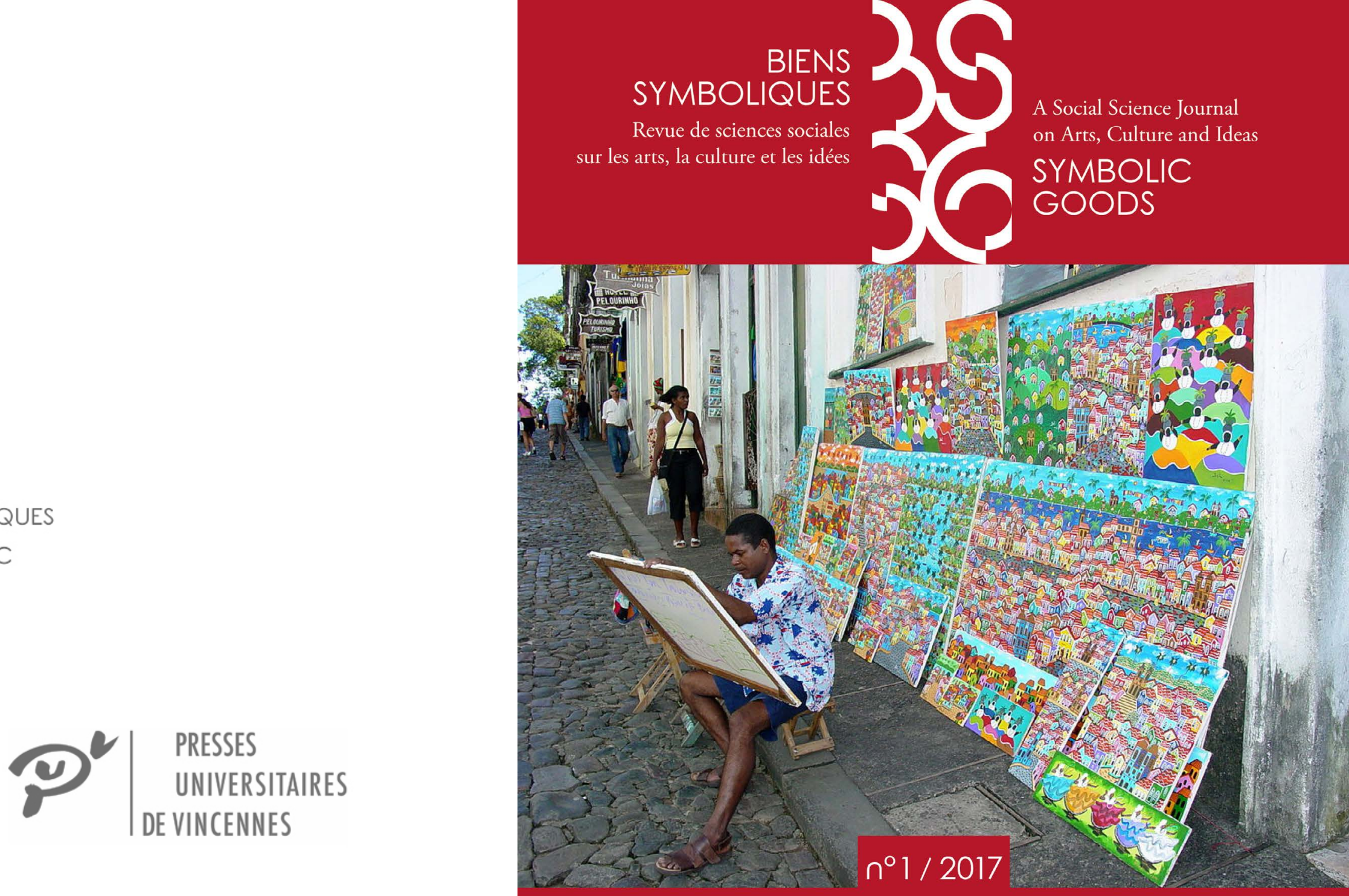

\section{Artistes ordinaires \\ Ordinary Artists}




\section{Le dessinateur de fabrique (XVIII ${ }^{e}-X_{1 X}$ siècle)}

Dans l'ombre de l'atelier
Factory Draughtsmen in Eighteenthand Nineteenth-Century France

The Forgotten Artists of the Workshop

\author{
Audrey Millet \\ traduction | translation \\ Jean-Yves Bart
}

\begin{abstract}
La « double historicisation », selon Pierre Bourdieu, est une opération aussi ardue que nécessaire pour toute recherche : elle implique, en effet, d'historiciser à la fois son objet d'étude et ses propres concepts (Bourdieu 2013). Bourdieu conseille ainsi de manier avec prudence les dénominations, de les replacer dans leur contexte d'énonciation ou leur «profondeur historique » (Sofio 2014). L'étude des " dessinateurs de fabrique », c'est-à-dire des dessinateurs chargés (généralement de façon anonyme) de la décoration d'objets manufacturés, montre effectivement que les raccourcis linguistiques tendent à fausser l'essence même du métier. «Dessinateur de fabrique » apparaît d'abord comme une catégorie professionnelle peu fiable. Elle est, en outre, rarement utilisée par les chercheurs, aujourd'hui, qui lui préfèrent les termes d'« artiste » ou d'« artisan » (Heinich 1993), séparant de fait l'application du dessin aux Beaux-Arts et son application à l'industrie. Toutefois, largement utilisée au xixe siècle, l'expression témoigne du fait qu'il existe bien un
\end{abstract}

"Double historicization," according to Pierre Bourdieu, is an arduous but necessary pre-requisite to any research. It consists in historicizing both one's research object and one's own concepts (Bourdieu 2013). Bourdieu thus advises a careful use of labels: placing them in the context in which they were used, or accounting for their "historical depth" (Sofio 2014). Studying French dessinateurs de fabrique, a term used to refer to the mostly nameless draughtsmen tasked with decorating manufactured objects, indeed shows that linguistic shortcuts can cause us to mischaracterize the very essence of a job. Dessinateur de fabrique is unreliable as a professional category. It is rarely used by today's researchers, who prefer the terms artiste (artist) and artisan (craftsman) (Heinich 1993), which in effect separate fine art and draughtsmanship for industrial purposes. However, the fact that this denomination was widely used in the nineteenth century shows that there is a point where the two categories meet. It also contributes to defining what may have constituted 
point de contact entre ces deux catégories tout en participant à la définition de ce que pouvait être un " artiste ordinaire » à cette époque. Alors que les règlements des corporations constituent le cadre de travail de la plupart des gens de métiers durant l'Ancien Régime, le dessinateur de fabrique exerce son activité librement - concrètement, cela signifie qu'il peut vendre ses productions sans l'aval d'un groupe de métier (Hanne \& Judde de Larivière 2010 ; Sewell 1983 ; sur les métiers libres, voir Thillay 2002). Si tous les dessinateurs de fabrique dessinent, c'est-à-dire qu'ils créent des décors et ordonnent des motifs, ces gestes et cette appellation sont communs à un ensemble varié de parcours et d'expériences

(Morvan-Becker 2010).

La première industrialisation, de 1750 aux années 1850, est un observatoire privilégié des évolutions technologiques et sociales à l'œuvre dans les manufactures. L'éventail des travaux des dessinateurs s'élargit en même temps que croissent la variété et la diffusion des produits à la mode. Ainsi, dans la seconde moitié du $\mathrm{XVIII}^{\mathrm{e}}$ siècle, vaisselle, cotonnades ou papiers peints ne sont plus exclusivement réservés à l'élite et sont en passe d'intégrer le quotidien de classes moins favorisées. La nouvelle économie de la consommation modifie les rapports de chacun aux objets et bouleverse les catégories traditionnelles d'analyse (par exemple : luxe vs objets du quotidien) (Roche 1997). La compétition entre les fabricants se joue largement sur le plan esthétique. Les dessinateurs deviennent donc, à cette époque, une clé de la réussite des manufactures qui font de la contribution de ces derniers leur meilleur argument de vente. an "ordinary artist" in those days. During the French Ancien Régime, rules laid out by corporations applied to most occupations, but factory draughtsmen worked freely-in the sense that they could sell their products without requesting permission from a trade group (Hanne \& Judde de Larivière 2010; Sewell 1980; on unregulated occupations, see Thillay 2002). While all factory draughtsmen drew, meaning that they created decorations and patterns, the label referred to individuals with a varied range of trajectories and experiences (Morvan-Becker 2010).

The first phase of industrialization, from the 1750s to the 1850s, was a key period for the observation of technological and social transformations at work in the factories. The scope of the draughtsmen's work broadened alongside the variety and breadth of products came into in fashion. In the second half of the eighteenth century, crockery, cotton fabrics, and wallpaper were no longer reserved for the elite; they became part of everyday lives outside of the upper classes. The new consumer economy changed individual relationships to objects and challenged traditional analytical categories (such as luxury versus everyday objects) (Roche 2000). The battle between manufacturers was largely fought on an aesthetic level. Draughtsmen therefore became key to their success, and their involvement was used as a selling point. 
Pourtant, le principal domaine d'activité des dessinateurs de fabrique - en l'occurrence, les végétaux et les ornements, récurrents dans les décorations - contribue à les inscrire au bas de la hiérarchie académique des arts. Celle-ci, définie en 1667 par André Félibien dans un discours à l'Académie royale de peinture et de sculpture, et toujours en vigueur dans la perception des arts au siècle suivant, organise les genres picturaux en catégories plus ou moins prestigieuses : la peinture d'histoire occupe le sommet de cette échelle ; elle est suivie du portrait, de la scène de genre, du paysage, et de la nature morte. Cette hiérarchie relègue donc théoriquement les dessinateurs de fabrique à une place inférieure parmi l'ensemble des artistes (Hardouin-Fugier \& Grafe 1992). Cette dépréciation générale a toutefois épargné la population des dessinateurs de fabrique lyonnais, chargés de dessiner pour l'industrie de la soie dont la ville s'est faite une spécialité. Les dessinateurs lyonnais, dont les créations servent de modèle aux tisserands, sont, en effet, supposés maîtriser le complexe métier à tisser. De plus, le fait qu'ils travaillent un matériau particulièrement luxueux - la soie - associé à la réputation prestigieuse de Lyon, entretenue par une abondante historiographie locale, ont, comme on va le voir, hissé les Lyonnais au panthéon des dessinateurs de fabrique (Leroudier 1908). On considère alors en outre que la technicité qu'implique le décor sur soie est bien supérieure à celle des décorations des cotonnades, des porcelaines ou des papiers peints, où le motif est appliqué - imprimé ou peint - sur l'objet, et non « intégré » à sa fabrication à l'instar du décor tissé de la soie. Ces autres techniques de décoration nécessitent pourtant la maîtrise de la gravure sur bois ou sur cuivre, et du travail sur l'objet en trois dimensions. Chaque secteur a
Despite this, the bulk of the activity of draughtsmenconsisting in drawing ornamental plants and decorationscontributed to their remaining within the lower levels of the academic hierarchy of the arts. The latter had been defined in 1667 by André Félibien in a speech to the Académie royale de peinture et de sculpture, and still applied in the following century. Félibien organized pictorial genres into categories with varying degrees of prestige: history painting was the most prestigious, followed by portraiture, genre art, landscape, and still life. In principle, this meant factory draughtsmen occupied a lower position than most artists (Hardouin-Fugier \& Grafe 1992). Yet factory draughtsmen in Lyon, tasked with working for the city's thriving silk industry, were spared this relegation. Their creations served as blueprints for weavers, and they were expected to master complex weaving looms. Additionally, the fact that they worked with a particularly upscale materialsilk-associated with Lyon's reputation, whose prestige was cultivated by an abundant local historiography, made them stand out and apart in the world of factory draughtsmen (Leroudier 1908). Drawing onto silk is considered to be technically far more difficult than drawing on cotton, china, or wallpaper, where the pattern is printed or painted onto the object after the latter is manufactured: it requires the pattern to be woven literally and figuratively into the silk. These other decorating techniques, however, required mastery of wood and copper engraving, and of work on three-dimensional objects; each sector had its own technical demands. The impression of homogeneity of expertise conveyed by the term dessinateur de fabrique was therefore particularly deceptive. Ultimately, the occupation of factory draughtsman must be approached in an open, interdisciplinary way. While art history 
ses spécificités techniques. L'impression d'homogénéité, en matière de savoir-faire, suscitée par l'expression « dessinateur de fabrique » est donc particulièrement fallacieuse. Ainsi, l'activité de dessinateur doit être saisie de manière décloisonnée et transversale. Si l'histoire de l'art étudie du point de vue stylistique et esthétique les travaux des dessinateurs, la nature industrielle de leur activité en fait avant tout, aux yeux des historiens, des ouvriers qualifiés. Situés à la croisée de l'économie et de l'art, inscrits dans un réseau de coopération où l'individualité compte autant que le collectif, les dessinateurs de fabrique forment un groupe, sans doute moins formalisé que celui d'une corporation, mais aux références et aux gestes identiques. Les dessinateurs de fabrique font partie des artistes ordinaires en ce qu'ils n'atteignent qu'exceptionnellement célébrité et statut très rémunérateur, mais également en ce qu'ils appliquent leur art aux objets du quotidien et ne sont pas dépourvus de « sauts intuitifs»-ces sauts de l'imagination que permet la conscience de son aptitude à modifier les choses (Sennett 2010, Vérin 1984 ; 1993). L'étude de leur travail sur les objets manufacturés induit donc la prise en compte des conditions économiques, de la hiérarchie et des exigences de qualité et

de créativité.

fichier Quick-Time Player Bruit du dessin : papier, mine graphite et vélin

(c) Audrey Mille

Pour mieux connaitre les dessinateurs de fabrique, j'ai recouru à des sources manuscrites, imprimées et graphiques variées qui m'ont permis de constituer une base de données prosopographique à partir de 3715 parcours de may study draughtmen's work in stylistic and aesthetic terms, the industrial nature of their activity means that they are first and foremost skilled workers in the eyes of historians. At the crossroads of art and trade and in a network of cooperation where individuality matters just as much as the collective, factory draughtsmen formed a group that was arguably less formalized than a corporation, but whose references and actions were shared. They were ordinary artists insofar as they very rarely became famous and well paid, but also because they applied their art to everyday objects and were capable of "intuitive leaps"-leaps of the imagination made possible by their awareness of their ability to change things (Sennett 2008, Vérin 1984, 1993). In order to study their work with manufactured objects, we must take into account their economic conditions, their hierarchy, and the requirements in terms of of quality and creativity.

fichier Quick-Time Playe Drawing sound: paper, lead, graphite, and vellum (c) Audrey Millet

To learn more about these factory draughtsmen, I used a variety of handwritten, printed, and graphic sources to compile a prosopographical database that comprises 3,715 trajectories of draughtsmen during the eighteenth and 
dessinateurs durant les $\mathrm{XVIII}{ }^{\mathrm{e}}$ et $\mathrm{XIX}$ e siècles (Millet 2016 ; $2017)^{1}$. Ces trajectoires à la fois individuelles et collectives de dessinateurs, ni « stars », ni « génies », sont marquées par une intense technicité, au croisement de l'art et de l'économie industrielle. Les dessinateurs de fabrique sont, en effet, aussi indispensables qu'invisibles dans le processus de création de l'objet manufacturé. Pourtant, à un moment précis de l'histoire, une minorité d'entre eux - les dessinateurs lyonnais travaillant pour l'industrie soyeuse - a pu être portée aux nues par les historiens. Nous reviendrons, dans une première partie, sur l'exceptionnelle inscription au panthéon local de ces « artistes ordinaires » pour en comprendre les modalités et les enjeux. Dans une deuxième partie, à rebours de ce cas particulier, nous examinerons la manière dont la célébration du dessin dans la littérature technique des $\mathrm{XVIII}$ et $\mathrm{XIX} \mathrm{X}^{\mathrm{e}}$ siècles a pu se faire sans que ne soit jamais évoquée sa mise en application concrète dans le cadre de la première industrialisation, assimilant de fait davantage les dessinateurs de fabrique à des ouvriers qu'à des artistes. Enfin, nous verrons comment la variabilité des dénominations a pu contribuer à l'invisibilité du groupe des dessinateurs jusqu'à ce que s'impose la formule « dessinateur de fabrique » à la

fin du XIX $X^{\mathrm{e}}$ siècle.

1 De manière non exhaustive, le corpus d'archives consultées comprend : des archives judiciaires ou notariales (mariages, inventaires après décès, faillites) des dossiers du personnel de décoration (notamment à la manufacture de Sèvres) ; de la littérature technique, des manuels d'apprentissage et des biographies de dessinateurs rédigées par des contemporains ; des sources graphiques, depuis le brouillon dessiné jusqu'à l'élaboration de l'objet en passant par l'esquisse finale. nineteenth centuries (Millet 2016;2017) ${ }^{1}$. These individual and collective trajectories of draughtsmen who were neither "stars" nor "geniuses" are characterized by their intensely technical nature, at the crossroads between art and industrial economy. Factory draughtsmen were both invisible and indispensable to the process of creating a manufactured object. However, at a specific moment in time, a minority of them-those working in the Lyon silk industry-were given the chance to step into the limelight of history. The first section examines how these "ordinary artists" made it into the local pantheon and what this meant. The second section moves on from this particular case to consider the absence of any mention of these draughtsmen and their working conditions during the first phase of industrialization in eighteen- and nineteenth-century technical literature, making them effectively workers rather than artists. The third and last section shows how the variety of labels used to refer to these draughtsmen contributed to their invisibility, until the term dessinateur de fabrique came to prevail in the late nineteenth century.

1 The corpus of archives I consulted comprises legal and notarial archives (marriages, estate inventories, bankruptcies); personnel files in decorating departments (including at the Sèvres factory); technical literature, learning manuals and biographies of draughtsmen penned by contemporaries; graphic sources (initial sketches, final designs, finished objects, etc.). 


\section{L'héroïsation des dessinateurs lyonnais : une exception qui confirme la règle?}

En 1787, dans son essai sur les manufactures et le commerce, Pierre Bertholon, membre de l'Académie des sciences de Montpellier, attribue clairement aux dessinateurs le succès des soieries lyonnaises : « N'oublie jamais, ô Lyon, que c'est à tes dessinateurs que tu dois en grande partie la prospérité de tes manufactures et que c'est à eux que tu es redevable de ces miracles de l'industrie que chaque jour voit éclore en ton sein » (Bertholon 1787 : 194). Dès cette époque, en effet, le travail du dessinateur suscite un intérêt croissant de la part de la cité. Cet intérêt est au fondement du culte, alors émergeant, du dessinateur-artiste lyonnais : celui-ci incarne l'association heureuse d'un précieux savoir-faire artistique et de l'industrie de la soie, pour la plus grande gloire de la ville.

Émile Leroudier (1870-1937), fils d'une brodeuse lyonnaise, dessinateur reconnu particulièrement investi dans les cercles locaux liés à l'industrie de la soie, devenu porte-parole de sa profession, est l'un de ceux qui portent ce discours d'une identité lyonnaise ancrée dans l'histoire manufacturière de la ville. II brosse, dans un texte publié au début du $\mathrm{xx}^{\mathrm{e}}$ siècle, le portrait idéal des « dessinateurs de la fabrique lyonnaise » en 67 notices (Leroudier 1908). Leroudier compile, en outre, le journal (ou Livre de raison) d'un dessinateur actif au XVIII' siècle (Miller 1998 ; Charpigny 2012). II réédite de même, avec des almanachs et des chroniques, le manuel du Dessinateur pour les étoffes d'or, d'argent et de soie de Nicolas Joubert de l'Hiberderie (1715-1770), fameux dessinateur pour soieries lyonnaises dont l'ouvrage, qui fournissait des indications techniques ou des conseils, avait été rédigé en 1765.

\section{How Lyon's draughtsmen came to be perceived as heroes: an exception to the rule?}

In his 1787 essay on factories and trade, Pierre Bertholon, a member of the Montpelllier academy of sciences, clearly attributed the success of Lyon's silk industry to the draughtsmen: "Never forget, O Lyon, that you owe to your draughtsmen much of the prosperity of your factories and that you are indebted to them for those miracles of industry that happen every day in your city" (Bertholon 1787: 194). Already at that time, the draughtsmen's work elicited a growing interest in the city. This interest was the basis of an emerging cult of the draughtsmen-artist in Lyon, which embodied the fortunate encounter between precious artistic skill and the silk industry, for the city's greatest glory.

Draughtsman Émile Leroudier (1870-1937), son of an embroiderer from Lyon, was very actively involved in local silk industry circles and became a spokesperson for his profession. He was among those who promoted a discourse on Lyon's identity that rooted it in the city's manufacturing history. In a text published in the early twentieth century, he painted the ideal portrait of the dessinateurs de la fabrique lyonnaise (Lyon's factory draughtsmen) in sixty-seven parts (Leroudier 1908). Leroudier also compiled the diary (or Livre de raison) of an eighteenth-century draughtsman (Miller 1998; Charpigny 2012). Along with almanacs and chronicles, he also reissued a 1765 draughtsman's manual of gold, silver, and silk fabrics by Nicolas Joubert de l'Hiberderie (17151770), containing technical instructions and tips. 


\section{T A B L E}

DE S M A T I E R E S.

F ptTRE dédicatoire,

$P_{R} \dot{E}$ ACE ,

GXTRAIT de quelques, Letteres écrites it PAuteur, xxxvi

TABLE fommaire du DESSIN A TEUR, $\mathrm{xlj}$

TABLE fommaire de $[$ ABECED AR1O, xlvij

I,E DESSINATEUR,

CHAP. I. Sa bits 2 lac, 2 lacs \& 2 lacs है? demi,

ibid.

CHAP. II. Damas \& Droguets fatinés, ;

CHAP. III. Perfienne \& Raz-de.Sicile. 10

CHAP. IV. Droguets liférés, fatinés, luftrinés, peruvienne \&s pruffẹine,

CHAP. V. Ti $\int u$, or \& argent, broché, 16

CHAP.VI. Taffetas façonné, Batayia

Florence broché,

CHAP.VII. Velours frifés, coupés, en dorure, chinés \& pluchés

23

CHAP. VIII. Taffetas chiné ou flambé, $3^{22}$

CHAP. IX. Taffetas broché en Joik etr dorure.

CHAP. $X$. Gros-de-Tours en foie $\&$ en ${ }^{37}$ rure,

CHAP. XI. Satin broché, réduit \& en dorure, \& damafquette,

CHAP, XII. Du Sans-nuance,
CHAP. XIII. Fond d'or \& Cirfaka; $50^{\circ}$

CHAP. XIV. Des.Mö̈res.

CHAP. XV. \& dernier, du Voyage de Paris,

TR'ADUCTION de fix Tables raifonnées, ex-

traites de l'A becedario Pittorico,

119

TABLE $I^{\text {re. }}$ Qui contient le nom des Livres qui traitent des Peintres, Ec. 121.

TABLE II. Qui contient les titres des Livres. d'Architecture, \&c.

I5 1

TABLE III. Qui traite des Livrés utiles,

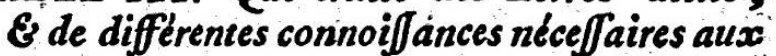
Definateurs,

165

TABLE IV. Confeils à la Jeuneffe qui veue faire des progres dans le Defein, i74

TABLB V: Diverfes connoiffances néceffaires \& utiles à cẹx qui font profefion de la Peinture.

178

TABLE VI. Inftruction pour peindre à frefque , fuivant la pratique des Experts, 204

Fin de la Table des Matieres.

Figure 1a. et 1b. Table des matières, Joubert de l'Hiberderie, Dessinateur pour les étoffes d'or, d'argent et de soie, 1765, non paginé Figure 1a. and 1b. Table of contents, Joubert de l'Hiberderie, Designer for Gold, Silver, and Silk Fabrics, 1765, not paginated 
À travers ces publications, Leroudier dresse le tableau d'un corps solidaire uni face à une situation de crise endémique. Or, il transpose le contexte de l'industrie lyonnaise du $\mathrm{XIX}{ }^{\mathrm{e}}$ siècle à celui du $\mathrm{XVIII}{ }^{\mathrm{e}}$ siècle, alors perçu comme l'apogée de la capitale de la soie. À rebours de ce qui se passe dans les manuels techniques à cette époque (ainsi que nous allons le voir dans la seconde partie de ce texte), Leroudier évacue totalement la technicité du métier des dessinateurs pour ne révéler que leur « génie » d'artiste. Ainsi, selon lui, Jean Revel (actif au début du XVIII ${ }^{\mathrm{e}}$ siècle) « sert encore de modèle aux plus habiles dessinateurs : ils le regardent comme leur Raphaël » (Leroudier 1908 : 12-13 ; Miller 1995 ; Thornton 1960).

Les mots de Leroudier rappellent ceux de Vasari dont les Vies d'artistes fondent le mythe du génie, autodidacte, précoce et inspiré (Vasari 2002 [1550]). Conformément aux topoï des biographies artistiques, les dessinateurs de Leroudier ont d'importantes prédispositions pour le dessin. La formation et l'histoire de l'école de dessin de Lyon, le nécessaire " voyage à Paris » - dont le récit des étapes est emprunté in extenso à Joubert de l'Hiberderie - finissent d'esquisser la culture des dessinateurs lyonnais. Ce portrait de Lyon et de ses artistes est rédigé à la gloire d'une industrie fatiguée dont l'âge d'or semble lointain, participant d'une identité reconstruite (Charpigny 2012). Le dessinateur de fabrique idéal y est dépeint à la fois comme un artiste et comme un homme de goût, lyonnais, lecteur cultivé, voire érudit, et forcément voyageur. Dans cette entreprise de reconstruction mémorielle, Leroudier fut, en fait, précédé par le dessinateur
Through these publications, Leroudier painted the picture of a united group in the face of an endemic crisis. Yet he transposed the context of the Lyon silk industry in the nineteenth century to that of the eighteenth century, which was then viewed as the silk capital's heyday. Unlike in other technical manuals of the time (as we will see in Part II), Leroudier's completely ignores the technical aspect of the draughtsmen's work, emphasizing only their "genius" as artists. In his words, Jean Revel (who was active in the early eighteenth century) "still served as a model to the most skilled draughtsmen: they looked up to him as their Raphael" (Leroudier 1908: 12-13; Miller 1995;

Thornton 1960).

Leroudier's words are reminiscent of Vasari's, whose Lives of the Painters, Sculptors and Achitects founded the myth of the self-taught, precocious, inspired genius (Vasari 1963 [1550]). In accordance with the tropes of artists' biographies, Leroudier's draughtsmen have major predispositions for their work. His portrait of Lyon's draughtsmen is complemented by an account of the emergence and the history of the Lyon school of draughtsmanship, and of the draughtsmen's inevitable "trip to Paris" - a section extensively borrowed from Joubert de l'Hiberderie. Leroudier was singing the praises of a flailing industry, whose golden age seemed remote, in an effort to reconstruct the city's identity (Charpigny 2012). He depicts the ideal factory draughtsman as an artist and a man of taste, a knowledgeable if not erudite reader, and of course as a traveller. This reconstruction of Lyon's history had in fact already been undertaken by the aforementioned draughtsman 

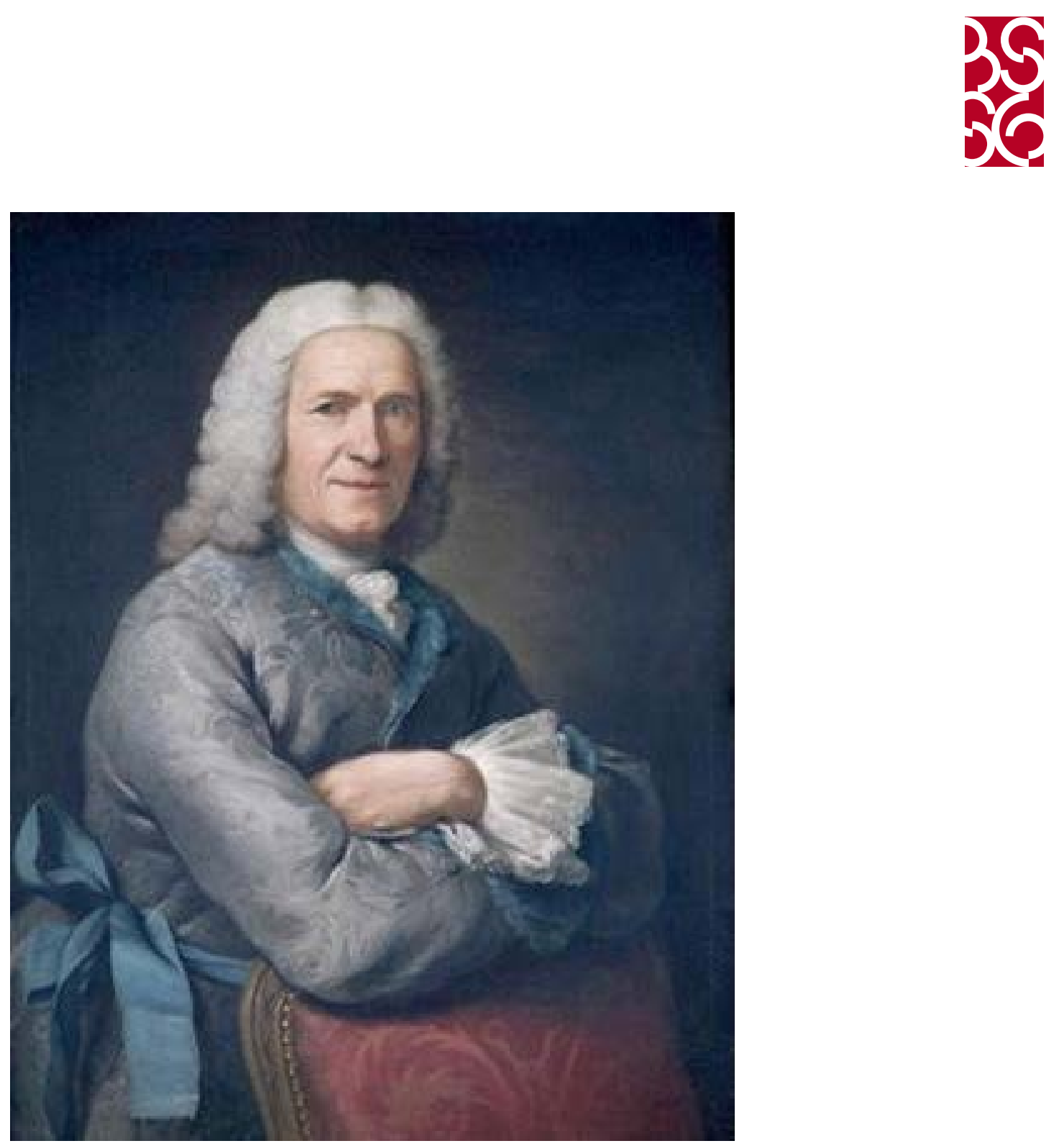

Figure 2. Portrait de Jean Revel, Donat Nonnotte (France, 1748, huile sur toile, $79 \times 64 \mathrm{~cm}$ ) Figure 2. Portrait of Jean Revel, Donat Nonnotte (France, 1748, oil on canvas, 31x24 in) Lyon, Musée des Tissus (Fabrics Museum)

(c) Lyon, Musée des Tissus, nv. n 1398 [www.mtmad.fr, mise en ligne en 2015, consulté le 19/03/2017]. 
pédagogue Joubert de l'Hiberderie, mentionné plus haut ; par le dessinateur pour soieries et peintre lyonnais formé à Paris, Joseph Guichard (1806-1880), dont les parents dirigeaient une boutique de papiers peints ; ou encore par Natalis Rondot (1821-1900). Économiste, industriel du textile et grand amateur d'arts, Rondot fut chargé de missions internationales pour le développement de l'industrie et du commerce. Comme historien de l'art, en outre, il est le concepteur du musée d'Art et d'Industrie de Lyon, dans le cadre duquel il travaille à la régénérescence de l'industrie de la soie lyonnaise. Tous sont à l'origine de ce culte du dessinateur lyonnais, dont la célébration implique l'effacement de tout ce qui peut le rattacher au monde de l'artisanat (Miller 2004 ; Chazelle

1992).

En conséquence, au fur et à mesure que la mémoire du travail technique lyonnais est éliminée, c'est-à-dire au fur et à mesure que Lyon est « panthéonisée », les autres centres manufacturiers français sont négligés. Après un siècle de publications locales, la postérité a retenu le génie des peintres de fleurs appliqué à la soie, soldant opportunément le débat entre artiste et artisan. La postérité de cette image du dessinateur de fabrique héroïsé oblige à se tourner vers d'autres sources pour saisir la réalité du groupe professionnel, au-delà de quelques figures exceptionnelles. La littérature technique qui se développe largement au $\mathrm{XVIII}^{\mathrm{e}}$ siècle constitue une source alternative, largement orientée vers le travail artisanal. Pourtant, les dessinateurs n'y ont pas la place que

l'on pourrait attendre. and teacher Joubert de l'Hiberderie, by the Paris-trained Lyon silk draughtsman and painter Joseph Guichard (1806-1880), whose parents owned a wallpaper shop, as well as by Natalis Rondot (1821-1900). An economist, textile industrialist, and keen supporter of the arts, Rondot was tasked with international missions for the development of industry and trade. Additionally, in his capacity as an art historian, he founded Lyon's museum of art and industry, working there on regenerating Lyon's silk industry. All contributed to this cult of the Lyon draughtsman, whose celebration entailed removing all traces of his ties to the world of craftsmanship (Miller 2004; Chazelle 1992).

The consequence of this mythification, involving the whitewashing of the memory of Lyon's technical work, was that other French manufacturing centres were neglected. After a century of local publications, history remembered the genius of the silk flower painters, conveniently settling the artist-craftsman debate. The posterity of this heroic image of the factory draughtsman forces us to turn to other sources to comprehend the reality of this professional group, beyond a few exceptional figures. The body of technical literature that grew largely in the eighteenth century is an alternative source, primarily concerned with craftsmanship. 


\section{Le dessinateur, grand absent de la littérature technique du $\mathrm{xVIII}$ e siècle}

La littérature technique des Lumières s'applique à décrire précisément de nombreux métiers liés au commerce ou à l'industrie. Toutefois, dans ce mouvement, le dessinateur reste une nouvelle fois invisible et silencieux. Ainsi, les articles « dessein » (sic), « dessiner » et « dessinateur» de l'Encyclopédie présentent d'abord le dessin sous l'angle de son utilité comme base pour les autres arts (Diderot \& D'Alembert 1754, vol. 4). L'auteur du premier de ces articles, sur le dessin, est Claude Henri Watelet (1718-1786), membre honoraire de l'Académie royale de peinture. II décrit le dessin comme un « terme de l'art de la peinture », à la fois " production qu'un artiste met au jour avec le secours du crayon ou de la plume » et, plus largement, " art d'imiter par les traits les formes que les objets présentent à nos yeux ». Toujours dans l'Encyclopédie, cette vue académique est complétée par celle de Jacques-François Blondel, professeur d'architecture. Il élargit la signification à des applications utiles, comme l'architecture, considérant que le dessin ne s'adresse pas seulement à ceux qui se destinent aux «beaux-arts ». Enfin, les auteurs anonymes des articles « dessinateur » et " dessiner » s'opposent. Le premier, proche de la définition de Watelet, désigne « celui qui sait rendre au crayon les objets tels que la nature nous les présente [et] celui qui sait exécuter sur le papier, avec les crayons, des sujets d'imagination, et les représenter comme on les aurait vus dans la nature s'ils avaient existé ». Les compétences du dessinateur sont valorisées mais rien ne laisse entrevoir une application aux objets manufacturés. Dans le second, le dessin ne se limite

\section{Draughtsmen: the forgotten figures of Eighteenth-Century technical literature}

In the Enlightenment era, technical literature sought to provide detailed descriptions of numerous trade- and industryrelated occupations. Again, however, factory draughtsmen were entirely neglected. In Diderot \& D'Alembert's 1754 Encyclopaedia (vol. 4), the entries on dessein (drawing), dessiner (to draw), and dessinateur (drawer) mainly discuss drawing in terms of its usefulness as a basis for the other arts. The entry on drawing was written by Claude Henri Watelet (1718-1786), a honorary member of the Royal Academy of Painting. He describes drawing as a "term of the art of painting," both "a production made by an artist with the aid of a pencil or quill" and more widely the "art of imitating with lines the forms presented to our eyes by objects." In the Encyclopaedia, this academic approach is complemented by that of professor of architecture Jacques-François Blondel. $\mathrm{He}$ expands the definition of the term to useful applications such as architecture, under the assumption that drawing is not only for those who devote themselves to "fine art." Lastly, the anonymous authors of the entries on "drawer" and "drawing" are at odds. The "drawer," somewhat in line with Watelet, is defined as "he who knows how to render with a pencil objects as nature presents them to us [and] he who knows how to execute on paper, using pencils, imagined objects, and represent them as we would see them in nature if they existed." The drawer's skills are praised, but no connection whatsoever is made to an application to manufactured objects. On the other hand, "drawing" is not limited to the imitation of nature. It has broader applications, which was 
pas à l'imitation de la nature. II s'applique à un horizon plus étendu et plus conforme à la réalité par l'évocation notamment de la technicité du dessin des vernisseurs. Dès le XVIII ${ }^{e}$ siècle, l'expression « dessinateur de fabrique » est employée par les spécialistes de l'industrie mais il est pratiquement absent de more accurate - in particular, the technicity of varnishers" designs is mentioned. In the eighteenth century, the term dessinateur de fabrique was used by industry specialists but virtually absent from technical literature.

la littérature technique.

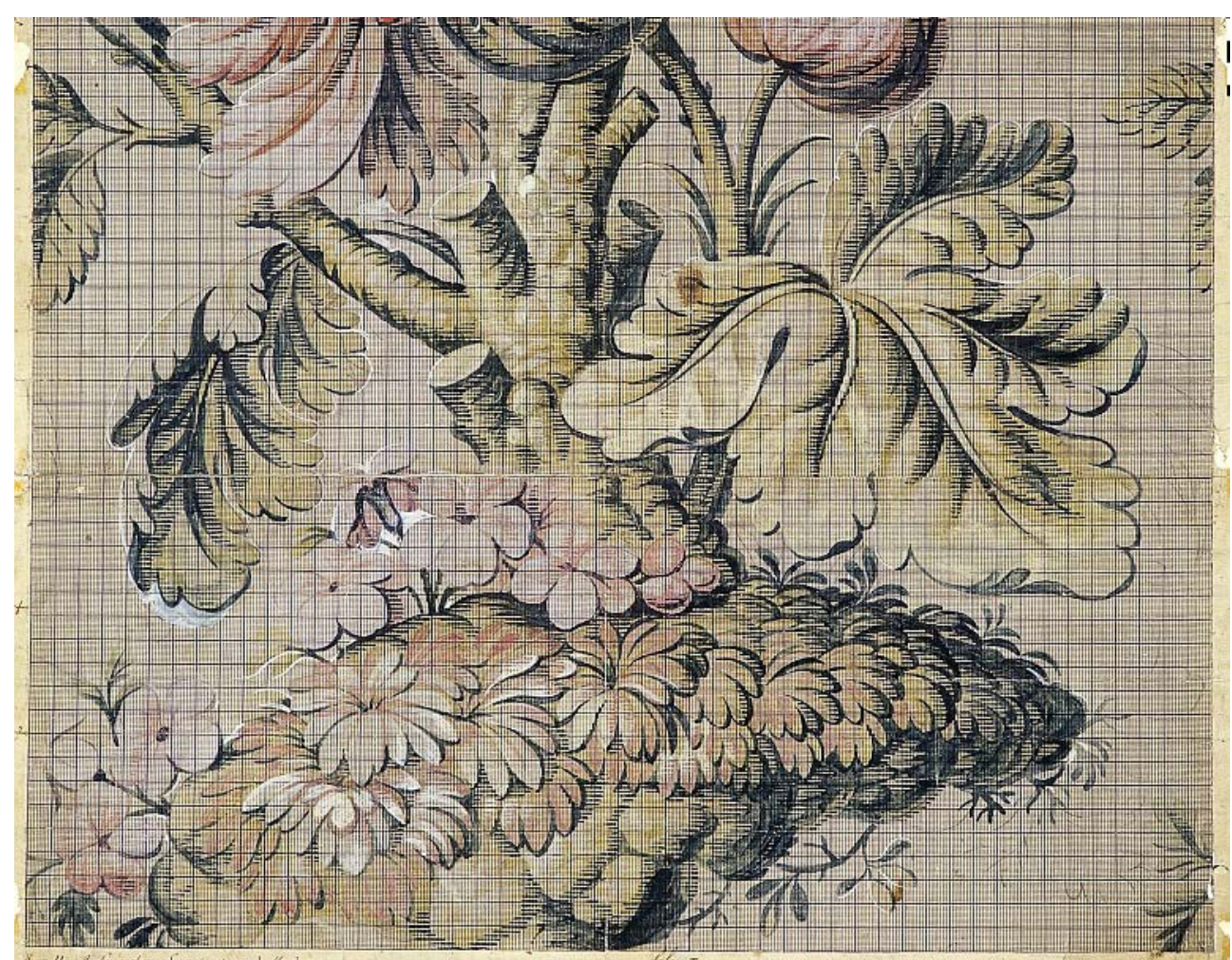

Figure 3. Mise en carte de Jean Revel, 1733

Figure 3. Map setting by Jean Revel, 1733

(c) Lyon, Musée des Tissus, inv. n 40932 [www.mtmad.fr, mise en ligne en 2015, consulté le19/03/2017]. 
Dans aucun de ces textes, surtout, les spécificités techniques du travail de dessinateur ne sont abordées. Pourtant, le dernier dessin du dessinateur, appelé « mise en carte », qui consiste à reporter le dessin sur un papier quadrillé représentant le textile à tisser, requiert de sérieuses connaissances

techniques

La figure 3 est une mise en carte réalisée par Jean Revel : elle est une représentation du métier à tisser en deux dimensions. Or, même dans les manuels les plus techniques, aucun auteur ne détaille cette étape capitale de la conception du décor. La mise en carte est bien rapidement évoquée dans l'article «velours » de l'Encyclopédie mais les indications apparaissent trop complexes pour l'amateur et trop laconiques pour le spécialiste (Diderot \& D'Alembert 1771, vol. 17). De même, dans son ouvrage (évoqué supra), Joubert de l'Hiberderie consacre 14 chapitres aux techniques de tissage, mais quelques lignes seulement à la mise en carte (Joubert de l'Hiberderie 1765 : 17). En aucun cas, le néophyte ne parviendrait à réaliser une carte pour soierie à partir de cette description. Quant au dessinateur et fabricant nîmois Bénard Paulet (actif dans la seconde moitié du XVIII siècle), il rythme son Art du fabricant (1773), seul « manuel » disponible avec celui de Joubert à l'époque, par des vignettes standardisées décrivant les étapes de fabrication des soies. Étrangement, le dessinateur est absent de l'ouvrage (Paulet 1773). On peut aussi noter qu'il y a, au même moment, un autre domaine, tout aussi technique, où le dessin est appliqué à la manufacture : la fabrique du papier peint. Or, pas un seul ouvrage technique ne décrit le travail dans ce secteur (Jacqué
Crucially, none of these texts discusses the technical specificities of the draughtsman's work. Yet, the draughtsman's final design-the mise en carte (point-paper plan)-which consists in transferring the pattern to a sheet of graph paper that represents the cloth to be woven, requires a great deal of technical knowledge.

Figure 3 is a mise en carte by Jean Revel: a two-dimensional representation of the weaving loom. Even in the most technical manuals, not a single author mentions this critical stage in the conception of a design. Mise en carte is mentioned in passing in the Encyclopaedia entry on "velvet," but the indications provided are too complex for amateurs and insufficiently detailed for specialists (Diderot \& D'Alembert 1771, vol. 17). Likewise, in his aforementioned book, Joubert de l'Hiberderie devotes fourteen chapters to weaving techniques, but only a few lines to mise en carte (Joubert de l'Hiberderie 1765 : 17): in no way would a neophyte be able to make a point-paper plan for silk based on that description. The Nimes-based draughtsman and manufacturer Bénard Paulet (active in the second half of the eighteenth century) included standardized figures describing the stages of silk manufacturing in his Art $d u$ fabricant (1773)-along with Joubert's, the only "handbook" available at the time. Curiously, draughtsmen are not mentioned in the book (Paulet 1773). It is also worth noting that at the same time, there was another equally technical field in which drawing was applied to manufacturing: the manufacturing of wallpaper. Yet, no technical book describes work in that sector (Jacqué 2003: 81), unlike weaving, which was at least the subject of a few, albeit partial, handbooks. 
$2003: 81$ ), contrairement au tissage qui fait au moins l'objet de quelques manuels - même partiels - comme on vient de

le voir.

II faut paradoxalement attendre les $\mathrm{XI} \mathrm{x}^{\mathrm{e}}$ et $\mathrm{X} \mathrm{x}^{\mathrm{e}}$ siècles, lorsque les métiers sont mécanisés et le langage de la mise en carte fortement normalisé, pour que des manuels apparaissent finalement dans le domaine du dessin technique (voir par exemple : Lemaire 1906). Comment expliquer les silences récurrents du $\mathrm{XVIII}^{\mathrm{e}}$ siècle ? II faut sans doute y voir une conséquence de la pratique du secret de fabrication et de la transversalité du métier de dessinateur qui permet de travailler librement pour plusieurs secteurs (porcelaine, dentelle, soie, indiennes). Le prestige de la Grande Fabrique lyonnaise et de ses travailleurs oriente ainsi le développement de la littérature technique et, plus largement, l'image du dessinateur. II faut donc diversifier les types de sources et leur origine géographique afin d'avoir un point de vue plus

général.

\section{Les mots pour le dire : des dénominations changeantes}

À Paris, les minutes de notaires, rédigées à l'occasion d'actes de mariage, de cessions d'entreprises ou d'inventaires aprèsdécès, témoignent d'une variété de dénominations. En 1851 par exemple, un dessinateur appliqué à la décoration des objets est appelé « dessinateur pour fabriques », « dessinateur lithographe ", « dessinateur créateur de tapis » ou encore
Paradoxically, it was not until the nineteenth and twentieth century, when these occupations had become mechanized and the process of mise en carte had become highly standardized, that handbooks on technical draughtmanship were finally published (see, for example, Lemaire 1906). This gap in the eighteenth century was arguably a consequence of an effort to safeguard trade secrets and of the versatility of the draughtsmen's job, allowing them to work freely in a variety of sectors (china, lace, silk, Indienne). The prestige of Lyon's Grande Fabrique (silk guild) and of its workers influenced the development of technical literature, and more broadly the image of draughtsmen. A more general overview can thus only be achieved by diversifying sources, in terms of type and geographical origin.

\section{Changing labels}

In Paris, notaries' records, containing information on marriage certificates, transfers of companies and estate inventories, attest to the use of a variety of terms to refer to draughtsmen. In 1851, for instance, a draughtsman who decorated objects could be called a dessinateur pour fabriques (factory draughtsman), a dessinateur lithographe (lithographer), a dessinateur créateur de tapis (rug designer), or a dessinateur 
« dessinateur sur étoffes »². La variété des désignations domine, par conséquent, et de nouvelles expressions apparaissent avec les pratiques lorsque les acteurs sont en position de nommer ce qu'ils font et de donner corps à ce qu'ils sont (Hilaire-Pérez 2008 : 233-289). Chacune de ces dénominations doit donc être replacée dans son contexte d'utilisation. Surtout, en toute logique, ces désignations évoluent en même temps que progresse l'industrialisation, d'autant que les dessinateurs ne travaillent plus un unique support. De nombreux dessinateurs décorent des indiennes (qui sont des tissus peints ou imprimés), des porcelaines et des papiers peints, sans distinction.

Cette apparente indécision lexicale témoigne ainsi non seulement de la position singulière des artistes dans l'industrie, mais aussi des mutations de cette dernière au cours des $X \mathrm{VIII}{ }^{\mathrm{e}}$ et $\mathrm{XIX} \mathrm{X}^{\mathrm{e}}$ siècles. On retrouve indifféremment « dessinateur » ou « metteur en carte » dans les Almanachs autour de 1800, mais soixante ans plus tard, les tampons et les cachets des cabinets, dans les manufactures, indiquent tous

2 Ces termes s'appliquent aussi bien aux Parisiens et aux Lyonnais qu'aux Mulhousiens. Archives nationales (désormais AN) MC, ET///454, acte de mariage $n^{\circ} 26610$, Trouvat Benoît, dessinateur-fabricant, 08 novembre 1751 ET/CXI/631, contrat de mariage, $n^{\circ} 50733$, Escallier Charles Alcide Norbert, dessinateur pour fabriques, 21 juin 1851 ; ET/LXX/185105-r51, acompte sur paiement de maison, $\mathrm{n}^{\circ} 39037$, Aucher Jean Gustave, 21 novembre 1851 $\mathrm{ET} / \mathrm{XXVI} / 1153$, contrat d'emploi, $\mathrm{n}^{\circ}$ 20281, Virolet Jean Baptiste Antoine, dessinateur créateur de tapis, 23 avril 1851; ET/LXXXIV/185109-r20, reprise après séparation de biens, $\mathrm{n}^{\circ}$ 45078, Fournier Alexis François, 21 octobre 1851. sur étoffes (fabric draughtsman) ${ }^{2}$. New terms appeared when actors were in a position to name what they did and to embody what they were (Hilaire-Pérez 2008: 233-289). Each of these labels should therefore be considered in light of the context in which they were used. Most importantly, and logically enough, these labels changed as industrialization progressed, especially as draughtsmen no longer worked on a single material. Many draughtsmen worked indifferently on Indiennes (printed or painted textiles), china, and wallpaper.

This apparent lexical indecision reflects not only the singular position of artists in industry, but also the mutations of industry in the eighteenth and nineteenth centuries. The terms dessinateur and metteur en carte were used interchangeably in almanacs around 1800 , but sixty years later, factory cabinets' stamps and seals all read dessinateur ${ }^{3}$. Could the

2 Such terms applied indifferently to draughtsmen in Paris, Lyon, and Mulhouse. Archives nationales (thereafter AN) MC, ET/I/454, acte de mariage no. 26610, Trouvat Benoît, dessinateur-fabricant, 08 novembre 1751 ; ET/ CXI/631, contrat de mariage, no. 50733, Escallier Charles Alcide Norbert dessinateur pour fabriques, 21 juin 1851 ; ET/LXX/185105-r51, acompte sur paiement de maison, no. 39037, Aucher Jean Gustave, 21 novembre 1851 ET/XXVI/1153, contrat d'emploi, no. 20281, Virolet Jean Baptiste Antoine, dessinateur créateur de tapis, 23 avril 1851 ; ET/LXXXIV/185109-r20, reprise après séparation de biens, no. 45078, Fournier Alexis François, 21 octobre 1851.

3 Cité Internationale de la dentelle et de la mode, Calais, Fonds Davenière Cartons $\mathrm{D}$ et $\mathrm{J}$ (ca 1860/1880). Musée des Arts Décoratifs, Paris, Fonds Galais, BAD 4983, CC 109, vol. 42 (ca 1860). 
« dessinateur »3. La généralisation de l'expression serait-elle un signe de la reconnaissance d'un savoir-faire global non apparenté à un support spécifique ? En réalité, que ce soit dans les archives de la manufacture de Sèvres, de Jouy ou dans les actes notariés, l'utilisation d'une dénomination plus précise indique soit une spécialisation soit l'activité en cours par le dessinateur désigné. Dans la hiérarchie académique des arts, évoquée plus haut, les genres sont organisés selon leur prestige. Mais il s'avère que les artistes de l'industrie utilisent tous ces genres à la fois. Notons également que les fabricants n'affectionnent pas la haute spécialisation. En effet, elle limite les savoir-faire et la mobilité des travailleurs en entreprise, entraînant ainsi des déceptions chez les manufacturiers. Le cadre de travail des dessinateurs de fabrique et la chaîne de fabrication créent ainsi un trompe l'œil qui déforme la vision que l'on peut avoir des compétences et des savoirs de ces artistes ordinaires. Le commun des dessinateurs est couramment considéré comme spécialisé dans la fleur, l'ornement ou le panoramique. generalization of that term attest to the recognition of a skillset that was not connected to a specific material? In practice, both in the archives of the Sèvres factory and in deeds drawn up by a notary, the use of a more specific label indicates either a specialization or the draughtsman in question's current activity. In the academic hierarchy of arts, genres are organized according to prestige. But the artists working for the industry were working within all of those genres. Also, manufacturers were not keen on high specialization, which limits the workers' skillsets and mobility. The working environment of the factory draughtsman and the manufacturing chain thus distort our vision of the skills and knowledge of these ordinary artists. Draughtsmen were usually considered to be specialized in flowers, ornaments, or panoramic designs.

3 Cité internationale de la dentelle et de la mode, Calais, Fonds Davenière Cartons D et J (vers 1860/1880). Musée des Arts Décoratifs, Paris, Fonds Galais, BAD 4983, CC 109, vol. 42 (vers 1860). 


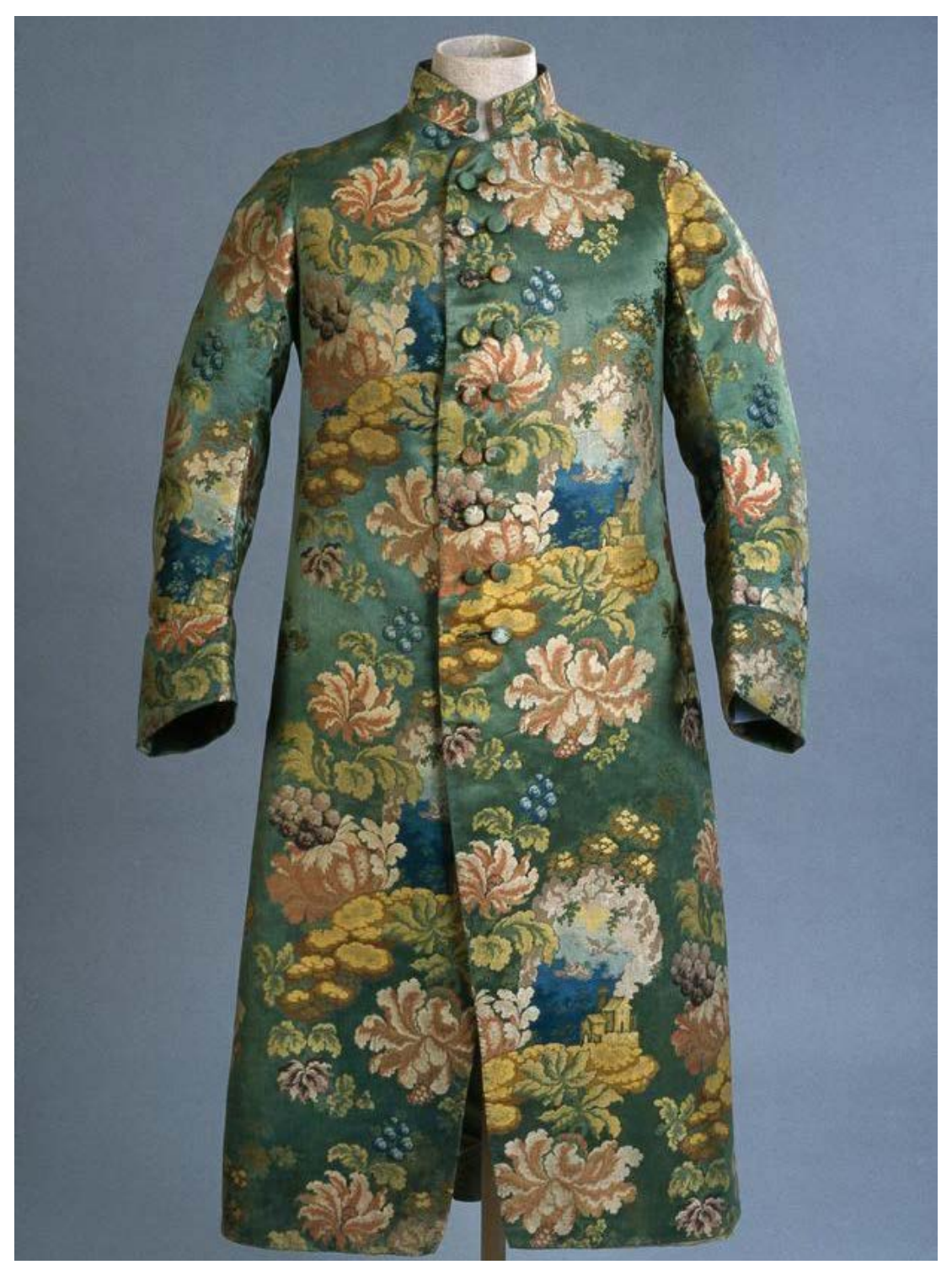

Figure 4. Banyan, France, 1735-1740, coupe vers 1780 , soie Figure 4. Banyan, France, 1735-1740, section made around 1780, silk (c) Royal Ontario Museum, Toronto, inv. n 909.33.1. 
Il faut bien admettre que les végétaux occupent une place de choix dans l'habillement. Pourtant, dans sa Grande Helvétie (papier peint, 1814), Pierre Mongin montre qu'il est capable de tout dessiner, paysages, personnages, architectures ou encore animaux, dans le but de transformer un intérieur.

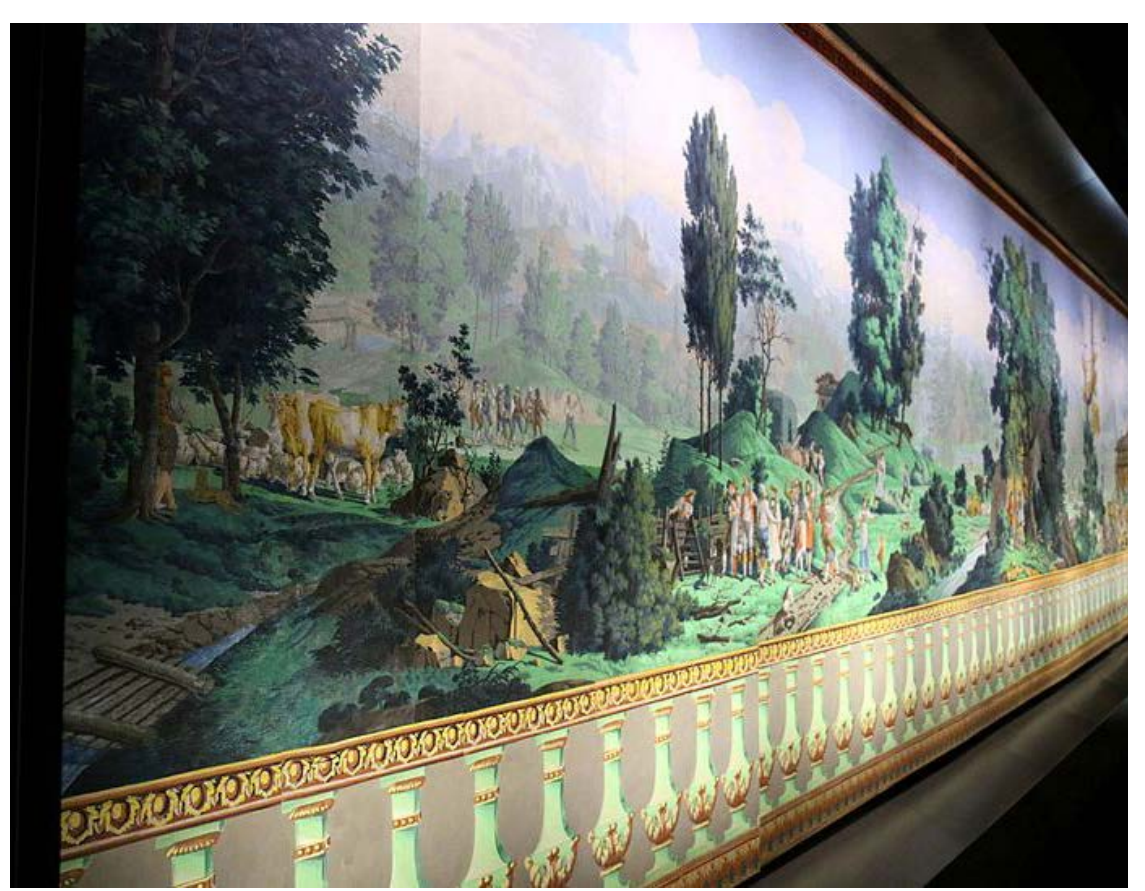

Admittedly, plants did have a prominent place in the clothing industry. However, in his Grande Helvétie (wallpaper from 1814), Pierre Mongin demonstrated that he was capable of drawing anything: landscapes, characters, architectures, animals, etc. for the purpose of transforming an interior.

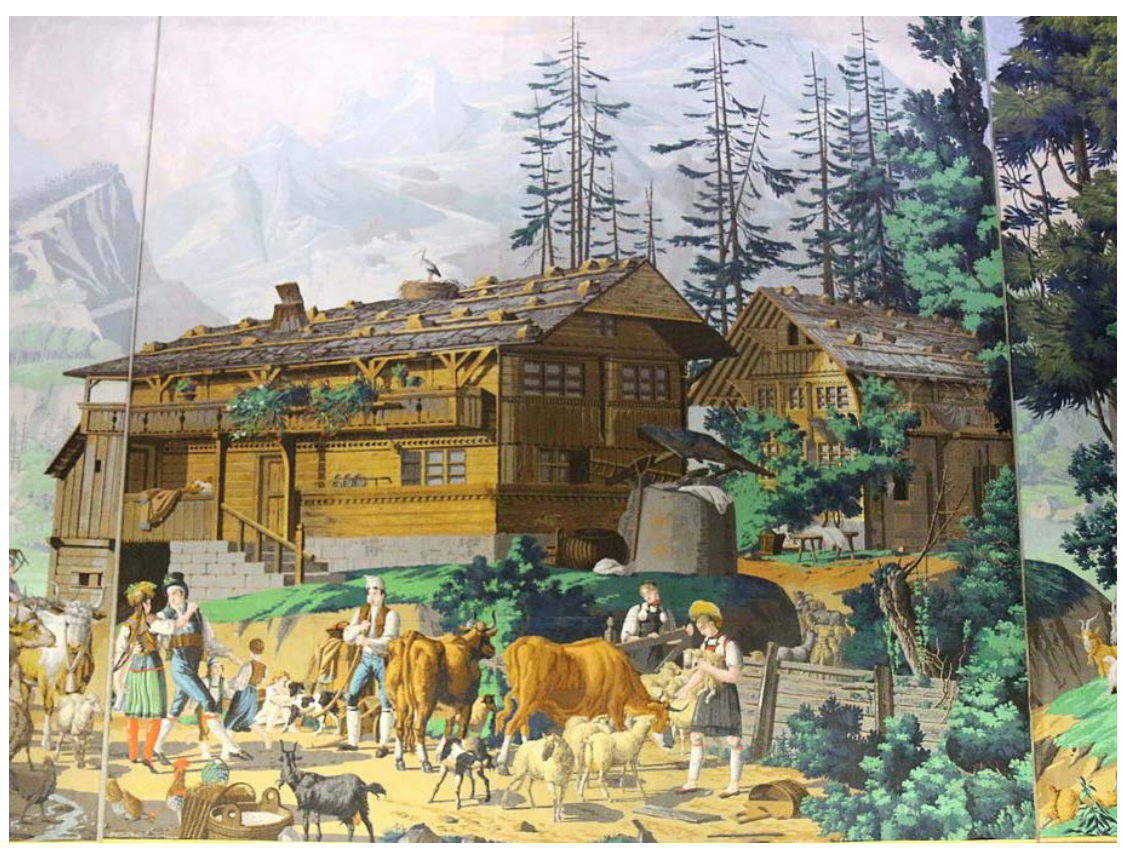

Figure 5a. Papier peint, Pierre Antoine Mongin, la Grande Helvétie, manufacture Zuber, 1814 Figure 5a. Wallpaper, Pierre Antoine Mongin, Great Helvetia, Zuber factory, 1814.

Figure 5b. Papier peint, Pierre Antoine Mongin, la Grande Helvétie, manufacture Zuber, 1814 (détail). Figure 5b. Wallpaper, Pierre Antoine Mongin, Great Helvetia, Zuber factory, 1814 (detail) 
Dans une carrière, un dessinateur a plusieurs champs de compétences en fonction des commandes sur lesquelles il travaille, c'est-à-dire en fonction de la main d'œuvre disponible au moment où la commande est passée. L'extrême spécialisation des dessinateurs est un mythe, tout comme l'image des héros de la fabrique.

Qu'en est-il de l'expression « dessinateur de fabrique »? Du milieu du $X V I I I^{e}$ siècle à la fin $d u X X^{e}$ siècle, le terme s'impose sans pour autant exclure d'autres dénominations. La banalisation de son usage est confirmée par Ngram Viewer [https://books.google.com/ngrams], l'outil d'analyse textuelle mis à disposition par Google pour mesurer dans le temps la fréquence d'un mot ou d'un groupe de mots dans l'ensemble des livres numérisés par Google Books. L'outil a bien des défauts et il ne saurait se substituer à l'analyse des sources, quantitatives et qualitatives. Néanmoins, les 45 milliards de mots répertoriés sur un corpus de 5,2 millions de livres en français permettent sans conteste de changer d'échelle en mettant à notre disposition un corpus dont la taille est totalement inédite. De 1720 à 1880, « dessinateur de fabrique » apparaît dans 136 ouvrages et articles. Durant le $\mathrm{XVIII}$ e siècle, " dessinateur de fabrique » est une formule extrêmement minoritaire dans la littérature spécialisée. La tendance s'inverse par la suite : on constate même une inflation de l'usage de l'expression qui est de plus en plus utilisée au fur et à mesure qu'on avance vers la fin du XIX
During their careers, draughtsmen had several areas of skill depending on the commissions on which they workedmeaning by extension depending on the available workforce at the time of the commission. The idea that draughtsmen were highly specialized is a myth, just like their image as manufacturing heroes.

The term dessinateur de fabrique prevailed from the mideighteenth until the late nineteenth century, but it did not supplant all other denominations. Its increasingly widespread use in that period is confirmed by Google's textual analysis tool Ngram Viewer [https://books.google.com/ngrams], which can search for occurrences of a word or group of words in all Google Books. Ngram Viewer has many flaws and should not replace the analysis of quantitative and qualitative sources. However, by inventorying some 45 billion words in a corpus of 5.2 million French-language books, it allows for a completely unprecedented change of scale. Between 1720 and 1880, dessinateur de fabrique appeared in 136 books and articles. In the eighteenth century, dessinateur de fabrique was used very little in the specialized literature. An inverse trend is then observed: the term was used increasingly frequently throughout the nineteenth century

siècle. 


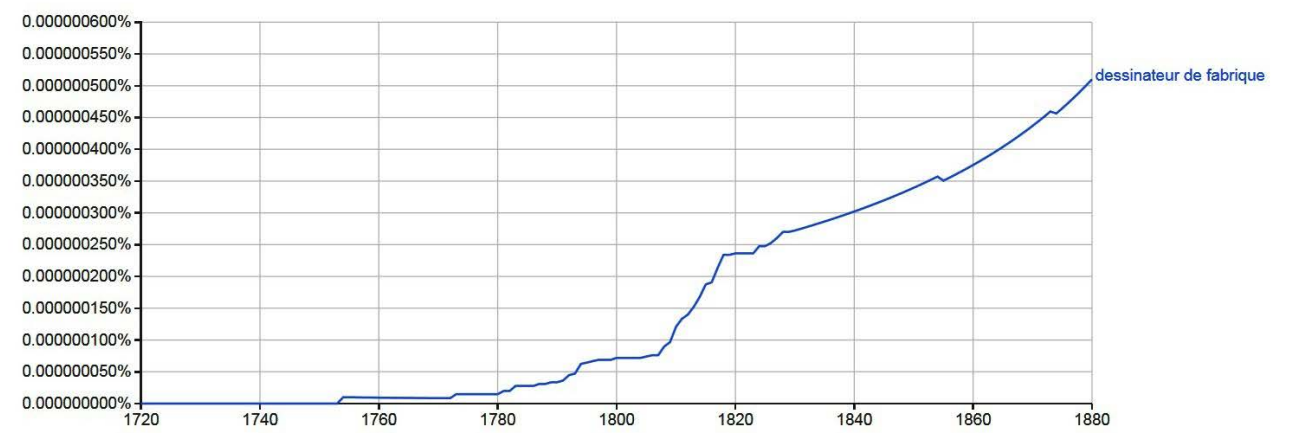

Figure 6. Analyse des occurrences de la formule « dessinateur de fabrique » dans les ouvrages numérisés par GoogleBooks (Google Ngram Viewer) selon l'année de publication : Figure 6. Google Ngram Viewer : "fabric designer" occurrence analysis

(c) Google Ngram Viewer

Cet emballement correspond à la stabilisation de l'expression - et à un nombre plus important de numérisations disponibles sur l'application pour le $\mathrm{XIX}^{\mathrm{e}}$ siècle - ce qui n'invalide pas pour autant les résultats.

Ainsi, le contexte de compétition internationale entre les manufactures et l'importance croissante de la décoration pour séduire la clientèle jouent en faveur du groupe des dessinateurs. Ils ne sont, à ce moment, plus nommés par leur spécialisation mais par leur application à l'industrie. Un groupe professionnel s'affirme en même temps que le secteur des arts appliqués se définit et que la compétition industrielle et internationale s'accroît. Ce graphique permet donc de comprendre que le dessinateur de fabrique occupe une place croissante dans la littérature à partir des années 1780. Le métier est alors compris dans son homogénéité et
This increase reflects the standardization of the term - as well as the greater availability of digitalized works for that period, but not to an extent that invalidates the results.

Ultimately, the international competition between manufactures and the growing importance of decoration to attract customers worked in the draughtsmen's favour. They were at that time not labelled according to their specialization, but on the basis of the industrial applications of their work. They emerged as a professional group at the same time as the applied arts sector was shaped and international industrial competition grew. Factory draughtsmen gained prominence in the literature from the 1780s and onwards. Their job became understood in its homogeneity and unity, in a way that did not prevent specialities being taken into account in specific contexts. 
son unité sans pour autant interdire de saisir une spécialité dans des contextes d'énonciation particuliers.

\section{Conclusion}

Les dessinateurs en indiennes ou céramiques sont des artistes ordinaires pour plusieurs raisons. D'une part, ils sont prisonniers du discours académique produisant une opposition entre arts mineurs et art majeurs, entre art et industrie. D'autre part, le cadre de production, la manufacture reste mal connue, généralement abordée sous l'angle de I'histoire des relations entre patrons et ouvriers ou sous celui de la hiérarchie interne aux fabriques (Chassagne 1980 ; 1991 ; Dewerpe \& Gaulupeau 1990). Ainsi, les relations entre l'art et la fabrique, et les conditions de travail des dessinateurs ont été peu étudiées. Enfin, dans une période de profondes et rapides évolutions industrielles, les contemporains de ces artistes cherchent encore les mots pour nommer un métier au

savoir transverse et en pleine mutation.

La nature de l'objet, fonctionnel et utilitaire, sur lequel travaillent les dessinateurs de fabrique contribue à les rejeter dans les marges de l'art ou à les rendre invisibles, car l'art ne serait pas compatible avec la mise en série et en vitrine. Or, tout comme les autres artistes, les dessinateurs de fabrique imitent et recomposent la nature dans leurs créations (HilairePérez 2008 ; Damisch 1982 ; Scott 1999 : 61-73). La répétition du geste et l'habitude s'opposeraient, de même, à la géniale spontanéité du peintre. Pourtant, « la singularité de l'action dans l'expérience définit une rationalité conçue non comme l'application d'une méthode, ni même une capacité de calcul

\section{Conclusion}

Factory draughtsmen were ordinary artists for several reasons. First, they were prisoners of the academic discourse which opposed minor and major arts, arts and industry. Secondly, the production environment of the factory remains littleknown, generally addressed under the angle of the history of relationships between bosses and workers, or of their internal hierarchies (Chassagne 1980; 1991; Dewerpe \& Gaulupeau 1990). Thus, the relationships between art and the factory, and the working conditions of draughtsmen have remained under-investigated. Lastly, at a time of fast and far-reaching industrial transformations, these artists' contemporaries were still searching for words to name an occupation that involved multiple skills and was changing quickly.

The functional, utilitarian nature of the objects on which factory draughtsmen worked contributed to relegating them to footnotes of the art world or to making them invisible, under the belief that art is not compatible with manufacturing. Yet, just like other artists, factory draughtsmen imitated and rearranged nature in their creations (Hilaire-Pérez 2008; Damisch 1982; Scott 1999: 61-73). The routine, repetitive character of their acts is perceived to be at odds with the painter's inspired spontaneity. Yet the "singularity of action in experience defines a rationality conceived not as the application of a method, or even an ability to calculate the 
du sujet mais plutôt comme un engagement sensible et la mise en œuvre de "facultés innées" pour "faire face aux choses" » (Hilaire-Pérez $2008: 414$, note 17). Cette rationalité alternative, c'est, pour Gilbert Simondon, le « subconscient technique » des dessinateurs, c'est-à-dire l'intelligence du geste. Dans cette perspective, l'automatisation flexible des gestes au dessin devient compatible avec la standardisation et la production de masse : les inconscients techniques et d'usage forment un outillage mental disponible durant le travail (Simondon 1958, p. 89). Le cas du dessinateur de fabrique montre ainsi qu'en tant qu'artiste ordinaire, son expérience n'est pas individuelle mais collective.

Le dessinateur de fabrique maîtrise un savoir-dessiner complexe, langage à la fois esthétique, technique, économique et culturel global, entre action individuelle, coopération et ordre négocié, formant ainsi les mondes du dessin de fabrique. Pour les puristes de la hiérarchie des arts, commerce, stratégie, utilité et technicité relèguent le dessinateur de fabrique à une place subalterne. Pourtant, le peintre d'histoire, lui aussi, répète son geste dès l'apprentissage, organise ses habitudes et les modifie, travaille avec des fournisseurs, multiplie les esquisses, possède une clientèle et touche une rémunération. Finalement, s'il y a des cas de déviance dans le travail artistique, ne concerneraient-ils pas plutôt les « stars », les «exceptions » que sont les artistes fameux dans les mondes de l'art? subject, but rather as an engagement of the sense and the deployment of 'innate faculties' to 'face things'" (Hilaire-Pérez 2008: 414, n. 17). Gilbert Simondon calls this alternative rationality the "technological unconscious" of draughtsmen; in other words, the intuitive intelligence of their gestures. In this sense, the flexible automatization of the draughtsman's work is compatible with standardization and mass production: the unconscious aspects of technological action and usage are mental tools that are available during work (Simondon 1958). The experience of the factory draughtsman has thus been shown to be, as an ordinary artist, more collective than individual.

Factory draughtsmen mastered a complex skillset, a language that was aesthetic, technical, economic, and cultural, between individual action, cooperation and negotiated order, shaping the world of factory draughtsmanship. To the purists of artistic hierarchy, factory draughtsman were inferior artists due to the commercial, strategic, utilitarian, and technical dimensions of their work. Yet history painters also repeated the same actions throughout their careers, organized and changed their habits, worked on commissions, made multiple sketches, had customers, and received remuneration. Perhaps if cases of deviance are to be found in artistic labour, they might relate to the few artists who rise to fame, the exceptional "stars"?

Audrey Millet Max Weber Fellow, Departement of History and Civilization, European University Institute IDHE.S/CNRS UMR 8533 http://www.idhes.cnrs.fr/ 


\section{Références bibliographiques}

BERTHOLON Pierre (1787). Du commerce et des manufactures distinctives de la ville de Lyon. Montpellier, Jean Martel Aîné.

BouRdieu Pierre (2013). Manet. Une révolution symbolique. Paris, Seuil. Chassagne Serge (1980). Oberkampf : un entrepreneur capitaliste au siècle des Lumières. Paris, Aubier-Montaigne.

Chassagne Serge (1991). Le Coton et ses patrons. France, 1760-1840. Paris, Éditions de l'EHESS.

DAMISCH Hubert (1982). « De la manufacture comme œuvre d'art économique à l'œuvre d'art comme machine ». Revue des sciences humaines, 186-187 : 307-320.

CHAZELLE René (1992). Joseph Guichard : peintre lyonnais (1806-1880), disciple d'Ingres et de Delacroix. Lyon, Presses Universitaires de Lyon.

Dewerpe Alain \& Gaulupeau Yves (1990). La Fabrique des prolétaires : les ouvriers de la manufacture d'Oberkampf à Jouy-en-Josas, 1760-1815. Paris, Presses de l'École normale supérieure.

Diderot Denis \& Le Rond D'Alembert Jean (1751). Encyclopédie ou dictionnaire raisonné des sciences, des arts et des métiers. Paris, Briasson, vol. 1.

Diderot Denis \& Le Rond D'Alembert Jean (1771). Encyclopédie ou dictionnaire raisonné des sciences, des arts et des métiers. Neufchatel, Société typographique, 17.

HANNE Georges \& JUDDE DE LARIVIĖRE Claire (dir.) (2010). Noms de métiers et catégories professionnelles. Acteurs, pratiques, discours (xve siècle à nos jours). Toulouse, Maison de la Recherche.

\section{References}

BeRTholon Pierre (1787). Du commerce et des manufactures distinctives de la ville de Lyon. Montpellier, Jean Martel Aîné.

Bourdieu Pierre (2013). Manet. Une révolution symbolique. Paris, Seuil. Chassagne Serge (1980). Oberkampf: un entrepreneur capitaliste au siècle des Lumières. Paris, Aubier-Montaigne.

Chassagne Serge (1991). Le Coton et ses patrons. France, 1760-1840. Paris, Éditions de l'EHESS.

DAMISCH Hubert (1982). "De la manufacture comme œuvre d'art économique à l'œuvre d'art comme machine." Revue des sciences humaines, 186-187: 307-320.

CHAZELLE René (1992). Joseph Guichard: peintre lyonnais (1806-1880), disciple d'Ingres et de Delacroix. Lyon, Presses Universitaires de Lyon.

DeWERPE Alain \& GaUluPEAU Yves (1990). La Fabrique des prolétaires: les ouvriers de la manufacture d'Oberkampf à Jouy-en-Josas, 1760-1815. Paris, Presses de l'École normale supérieure.

Diderot Denis \& Le Rond D'Alembert Jean (1751). Encyclopédie ou dictionnaire raisonné des sciences, des arts et des métiers. Paris, Briasson, vol. 1

Diderot Denis \& LE ROND D'AlEMBERT Jean (1771). Encyclopédie ou dictionnaire raisonné des sciences, des arts et des métiers. Neufchatel, Société typographique, vol. 17.

HANNE Georges \& JUDDE DE LARIVIĖRE Claire (eds.) (2010). Noms de métiers et catégories professionnelles. Acteurs, pratiques, discours ( $x v^{e}$ siècle à nos jours). Toulouse, Maison de la Recherche. 
Hardouin-Fugier Élisabeth \& Grafe Étienne (1992). Les Peintres de fleurs en France : de Redouté à Redon (suivi d'un répertoire des peintres). Paris, Éditions de l'Amateur.

HEINICH Nathalie (1993). Du peintre à l'artiste. Artisans et académiciens à l'âge classique. Paris, Minuit.

Hilaire-Pérez Liliane (2008). La Pièce et le geste. Entreprises, cultures opératoires et marchés à Londres au XVIII siècle (mémoire d'habilitation à diriger des recherches, histoire, Université Paris I). Version publiée : HILAIRE-PÉREZ Liliane (2013). La Pièce et le geste. Artisans, marchands et savoir technique à Londres au XVIII siècle. Paris, Albin Michel.

JACQUÉ Bernard (2003). De la manufacture au mur. Pour une histoire matérielle du papier peint (1770-1914) (thèse de doctorat en histoire). Lyon, Université Lyon 2.

JoUBERT DE L'HIBERDERIE Antoine-Nicolas (1765). Le Dessinateur pour les fabriques d'étoffes d'or, d'argent et de soie. Paris, Chez Sébastien Jorry. LemAIRE Henri (1906). La Valencienne : traité pratique de mise en carte de barres. Lille, Nuez.

LEROUDIER Émile (1908). "Les dessinateurs de la fabrique lyonnaise au XVIII' siècle ». Revue d'histoire de Lyon, 7 : 242-320.

Leroudier Émile (1930). Les Cahiers d'Étienne Benoit (1761-1771). Livre de Raison d'un Dessinateur de la Fabrique lyonnaise. Lyon, M. Camus et Carnet.

MiLlet Audrey (2016). «Transmettre le dessin de fabrique. Matérialité et immatérialité du livre technique en manufacture (XVIII $-\mathrm{xIX}{ }^{\mathrm{e}}$ siècle) 》. In Hilaire-Pérez Liliane, NèGre Valérie, SpicQ Delphine, Vermeir Koen (dir.). Le Livre technique avant le $x x^{e}$ siècle. À l'échelle du monde. Paris, CNRS Éditions : 77-95.
HARDOUIN-FugIER Elisabeth \& GRAFE Etienne (1992). Les Peintres de fleurs en France: de Redouté à Redon (suivi d'un répertoire des peintres). Paris, Éditions de l'Amateur.

HeINICH Nathalie (1993). Du peintre à l'artiste. Artisans et académiciens à l'âge classique. Paris, Minuit.

HILAIRE-Pérez Liliane (2008). La Pièce et le geste. Entreprises, cultures opératoires et marchés à Londres au XVIII siècle (Dissertation habilitation à diriger des recherches, History, Université Paris I). Published: HILAIREPérez Liliane (2013). La Pièce et le geste. Artisans, marchands et savoir technique à Londres au XVIII siècle. Paris, Albin Michel.

JACQUÉ Bernard (2003). De la manufacture au mur. Pour une histoire matérielle du papier peint (1770-1914) (PhD dissertation, History). Lyon, Université Lyon 2.

JoUBERT DE L'HIBERDERIE Antoine-Nicolas (1765). Le Dessinateur pour les fabriques d'étoffes d'or, d'argent et de soie. Paris, By Sébastien Jorry.

LemalRe Henri (1906). La Valencienne: traité pratique de mise en carte de barres. Lille, Nuez.

LEROUdier Émile (1908). "Les dessinateurs de la fabrique lyonnaise au XVIII' siècle." Revue d'histoire de Lyon, 7: 242-320.

Leroudier Émile (1930). Les Cahiers d'Étienne Benoit (1761-1771). Livre de Raison d'un Dessinateur de la Fabrique lyonnaise. Lyon, M. Camus and Carnet.

Millet Audrey (2016). "Transmettre le dessin de fabrique. Matérialité et immatérialité du livre technique en manufacture (XVIII-XIX ${ }^{e}$ siècle)." In Hilaire-Pérez Liliane, Nègre Valérie, Spicq Delphine, Vermeir Koen (eds.). Le Livre technique avant le $x x^{e}$ siècle. À l'échelle du monde. Paris, CNRS Éditions: 77-95 
Millet Audrey (2017). Dessiner la mode. Histoire des mains habiles (XVIII $-X I X^{e}$ siècle). Paris, Vendémiaire.

MiLleR Lesley (1995). « Jean Revel : Silk Designer, Fine Artist, or Enterpreneur? ». Journal of Design History, 8(2) : 79-96.

MILLER Lesley (1998). « Manufactures and the Man : A Reassessment of the Place of Jacques-Charles Dutillieu in the Silk Industry of Eighteenth Century Lyons ». Textile History, 29(1) : 19-40.

MILLER Lesley (2004). «Representing Silk Design. Nicolas Joubert de l'Hiberderie and Le Dessinateur pour les étoffes d'or, d'argent et de soie (Paris, 1765) ». Journal of Design History, 17(1) : 29-53.

MoRvAN-BECKER Frédéric (2010). L'École gratuite de dessin de Rouen ou la Formation des techniciens au XVIII siècle (thèse de doctorat en histoire). Saint-Denis, Université Paris 8.

PAULET Bénard (1773). L'Art du fabriquant d'étoffes de soie... par M. Paulet, dessinateur et fabricant en étoffes de soie de la ville de Nîmes. (Sans lieu), Chez Saillant et Nyon.

Roche Daniel (1997). Histoire des choses banales : naissance de la consommation dans les sociétés traditionnelles. $X V I I^{e}-X I X^{e}$ siècle. Paris, Fayard.

ScotT Katie (1999). «Chardin multiplié ». Chardin (catalogue d'exposition, Paris, Grand Palais). Paris, Réunion des musées nationaux : 61-73.

SENNETT Richard (2010). Ce que sait la main : la culture de l'artisanat. Traduction française par Pierre-Emmanuel Dauzat. Paris, Albin Michel.

SeWell William Hamilton (1983). Gens de métier et révolutions. Le langage du travail de l'Ancien Régime à 1848. Traduction française par Jean-Michel Denis. Paris, Aubier.
Millet Audrey (2017). Dessiner la mode. Histoire des mains habiles (XVIII $-X I X^{e}$ siècle). Paris, Vendémiaire.

MiLleR Lesley (1995). "Jean Revel: Silk Designer, Fine Artist, or Enterpreneur?.” Journal of Design History, 8(2): 79-96.

MiLLER Lesley (1998). "Manufactures and the Man: A Reassessment of the Place of Jacques-Charles Dutillieu in the Silk Industry of Eighteenth Century Lyons." Textile History, 29(1): 19-40.

MiLLER Lesley (2004). "Representing Silk Design. Nicolas Joubert de I'Hiberderie and Le Dessinateur pour les étoffes d'or, d'argent et de soie (Paris, 1765)." Journal of Design History, 17(1): 29-53.

MoRVAN-BECKER Frédéric (2010). L'École gratuite de dessin de Rouen ou la formation des techniciens au $x \mathrm{VIII}^{e}$ siècle ( $\mathrm{PhD}$ dissertation, History). Saint-Denis, Université Paris 8.

PAULET Bénard (1773). L'Art du fabriquant d'étoffes de soie... par M. Paulet, dessinateur et fabricant en étoffes de soie de la ville de Nîmes. (Without place), By Saillant et Nyon.

Roche Daniel (2000). A History of Everyday Things: the Birth of Consumption in France. 1600-1800. English translation by Brian Pearce. Cambridge, Cambridge Univetrsity Press.

Scotт Katie (1999). "Chardin multiplié." Chardin (exhibition catalogue, Paris, Grand Palais). Paris, Réunion des musées nationaux: 61-73.

Sennett Richard (2008). The Craftsman. New Haven, Yale University Press.

SEWELL William Hamilton (1980). Work and Revolution in France. Cambridge, Cambridge University Press. 
SoFIO Séverine (2014). « Manet ». Sociologie (« Comptes rendus »). [En ligne] http://sociologie.revues.org/2266 [consulté le 15 mars 2017].

SimONDON Gilbert (1958). Du mode d'existence des objets techniques. Paris, Aubier.

ThILLAY Alain (2002). Le Faubourg Saint-Antoine et ses «faux ouvriers »: la liberté du travail à Paris aux XVII et XVIII siècles, Seyssel, Champ vallon, 2002.

THORNTON Peter (1960). « Jean Revel, Dessinateur de la Grande Fabrique ». Gazette des Beaux-Arts : 71-86.

VASARI Giorgio (2002) [1550]. Vies d'artistes [Vite di artisti, Florence, Lorenzo Torrentino]. Traduction française par Gérard Luciani. Paris, Gallimard.

VÉRIN Hélène (1984). «Le mot : ingénieur ». Culture technique, 12 : 327 333.

VÉRIN Hélène (1993). La Gloire des ingénieurs. L'intelligence technique $d u X V l^{e}$ au XVIII siècle. Paris, Albin Michel.
SofıO Séverine (2014). "Manet." Sociologie ("Comptes rendus"). [On line] http://sociologie.revues.org/2266 [accessed on 15 march 2017].

SimONDON Gilbert (1958). Du mode d'existence des objets techniques. Paris, Aubier.

THILLAY Alain (2002). Le Faubourg Saint-Antoine et ses "faux ouvriers": la liberté du travail à Paris aux XVII et XVIII siècles. Seyssel, Champ Vallon, 2002.

THORNTON Peter (1960). "Jean Revel, dessinateur de la Grande Fabrique." Gazette des Beaux-Arts: 71-86.

VASARI Giorgio (1963) [1550]. The Lives of the Painters, Sculptors and Architects [Vite di artisti, Florence, Lorenzo Torrentino]. English translation by Allen Banks Hinds. New York, Dutton.

VÉRIN Hélène (1984). "Le mot: ingénieur." Culture technique, 12: 327-333.

VéRIN Hélène (1993). La Gloire des ingénieurs. L'intelligence technique du XVIe au XVIII siècle. Paris, Albin Michel. 